\title{
THE CLIMATE OF MACQUARIE ISLAND AND ITS ROLE IN ATMOSPHERIC MONITORING
}

\author{
by N.A. Streten
}

(with four tables, fourteen text-figures and one plate)

STRETEN, N.A., 1988 (viii): The climate of Macquarie Island and its role in atmospheric monitoring. Pap. Proc R. Soc. Tasm., 122(1): 91-106, 1 pl. Papers presented at the Macquarie Island Symposium, Hobart, May 1987. https://doi.org/10.26749/rstpp.122.1.91 ISSN 0080-4703. Bureau of Meteorology, G.P.O. Box $1289 \mathrm{~K}$, Melbourne, Australia 3001

An analysis is made of the principal climatic elements at Macquarie Island in relation to the general circulation of the high latitudes of the southern hemisphere. The climate is characterised by a high frequency of strong west to northwesterly winds and frequent gales, low variability of temperature, a high frequency of low cloud and fog, and a high number of days with precipitation throughout the year. In general, the climate is typical of a higher mid-latitude oceanic island, and its features are compared with others in the circumpolar Southern Ocean.

From a different perspective the island occupies a unique geographic site. This makes it extremely valuable as a meteorological observatory, enabling regular surface and upper air observations for day-to-day global analysis and forecasting, and providing climatic data representative of the higher southern mid-latitudes. Despite the advent of new observational techniques (such as satellite-reporting drifting ocean buoys, satellite cloud imagery and satellite-derived atmospheric temperature profiles), the observations from Macquarie Island continue to constitute essential calibration dat a for space-derived measurements and provide the long-term continuity only possible at a fixed baseline station. The importance of these data is stressed; not only with respect to the standard meteorological observations but also to the measurement of ozone, carbon dioxide and other atmospheric trace constituents which are becoming increasingly recognised as significant in studies of long-term climatic change.

Key Words: Macquarie Island, climatic change, meteorological observations, Southern Ocean, $\mathrm{O}_{3}$ "hole", $\mathrm{CO}_{2}$ increase.

"For days on end the upper plateau would be shrouded in mist and a great wall of fog would block out the sea on all sides. A fine misty rain would be falling continually and the inevitable wind sweeping in past the apparently inpenetrable fog barrier." (K.C. Hines, unpublished account of the first ANARE expedition of 1948)

\section{INTRODUCTION}

The weather and climate of Macquarie Island are best analysed by consideration of its geographical position relative to the broadscale atmospheric and oceanic circulation features of the Southern Hemisphere (fig. 1). Thus, its latitude $\left(54^{\circ} 30^{\prime} \mathrm{S}\right)$, just north of the Antarctic Convergence, its ocean location, far removed from the major land masses of Australia and Antarctica, and also, to a lesser but still significant extent, its longitude $\left(158^{\circ} 57^{\prime} \mathrm{E}\right)$ are critical in understanding the observed conditions. The present discussion will generally follow the approach of considering climatic data from the island within the framework of the broadscale general circulation of the hemisphere and also comparing it with observations at other Southern Ocean islands. Previous studies of the island's climate have been made by Newman (1929) and Kidson (1946), using data from the Mawson period (1911-14), and by Gibbs et al. (1952) analysing in some detail the observations of the first year of the Australian National Antarctic Research Expeditions (ANARE) in 1948. Complete observational data have been published by ANARE from 1948 to 1968 , and the entire records to date are held in readily accessible form in the Bureau of Meteorology's data bank in Melbourne.

\section{PRESSURE, WIND AND WEATHER SYSTEMS}

Figure 2, based on the data of Taljaard $e t a l$. (1969) and Jenne et al. (1971), shows the mean sea-level pressure and windspeed fields over the surrounding region in January and July, and indicates that the island lies throughout the year in the regime of the mid-latitude westerlies, between the subtropical anticyclones and the subpolar belt of low pressure surrounding Antarctica. The maps also show that the longitude of Macquarie Island is upstream of the mean pressure ridge extending south of the eastern Tasman Sea and New Zealand and downstream of the trough centred south of 


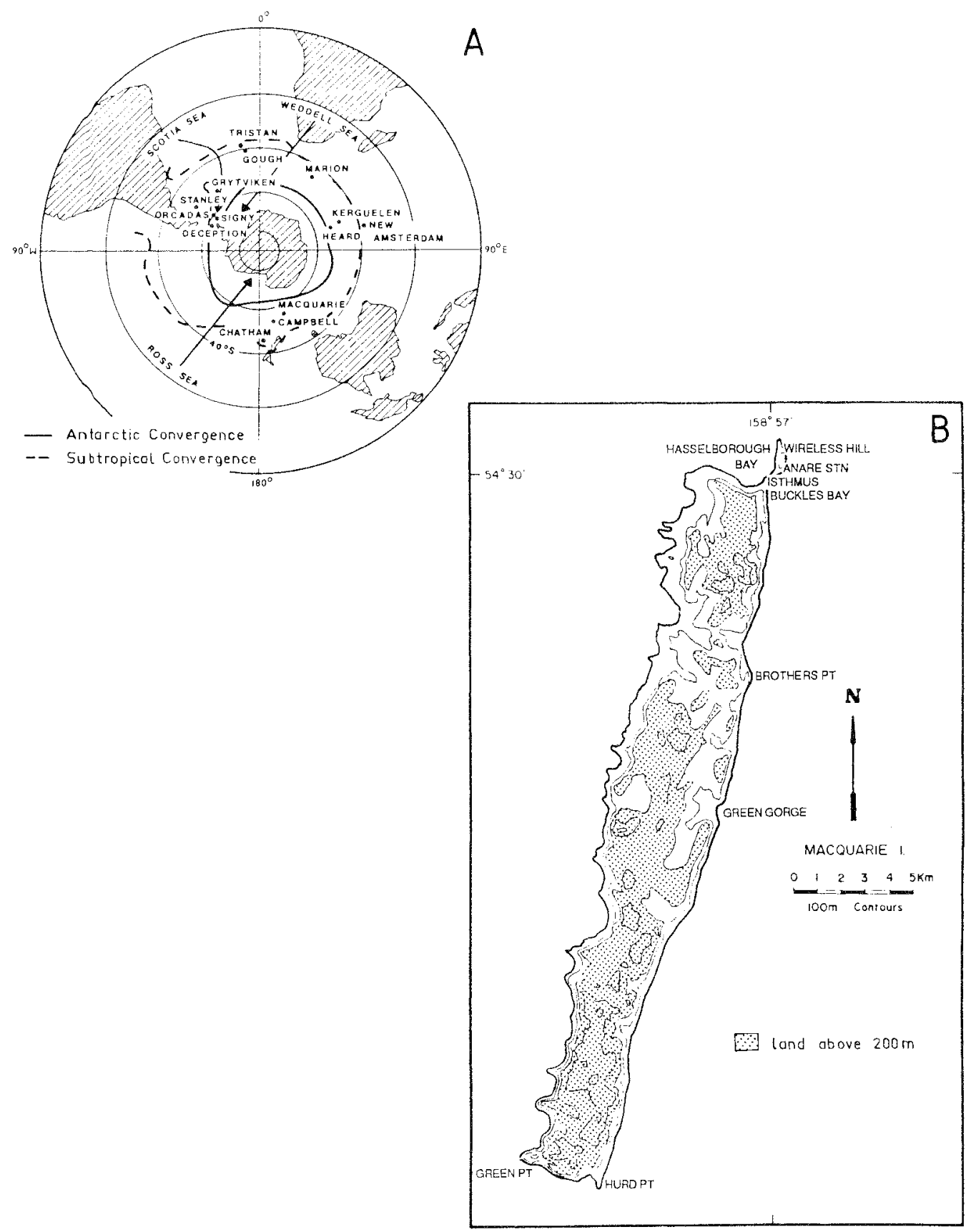

FIG. 1 - (A) The Southern Hemisphere (polar stereographic projection) showing relation of Macquarie Island to other places mentioned in the text.

(B) Macquarie Island. 

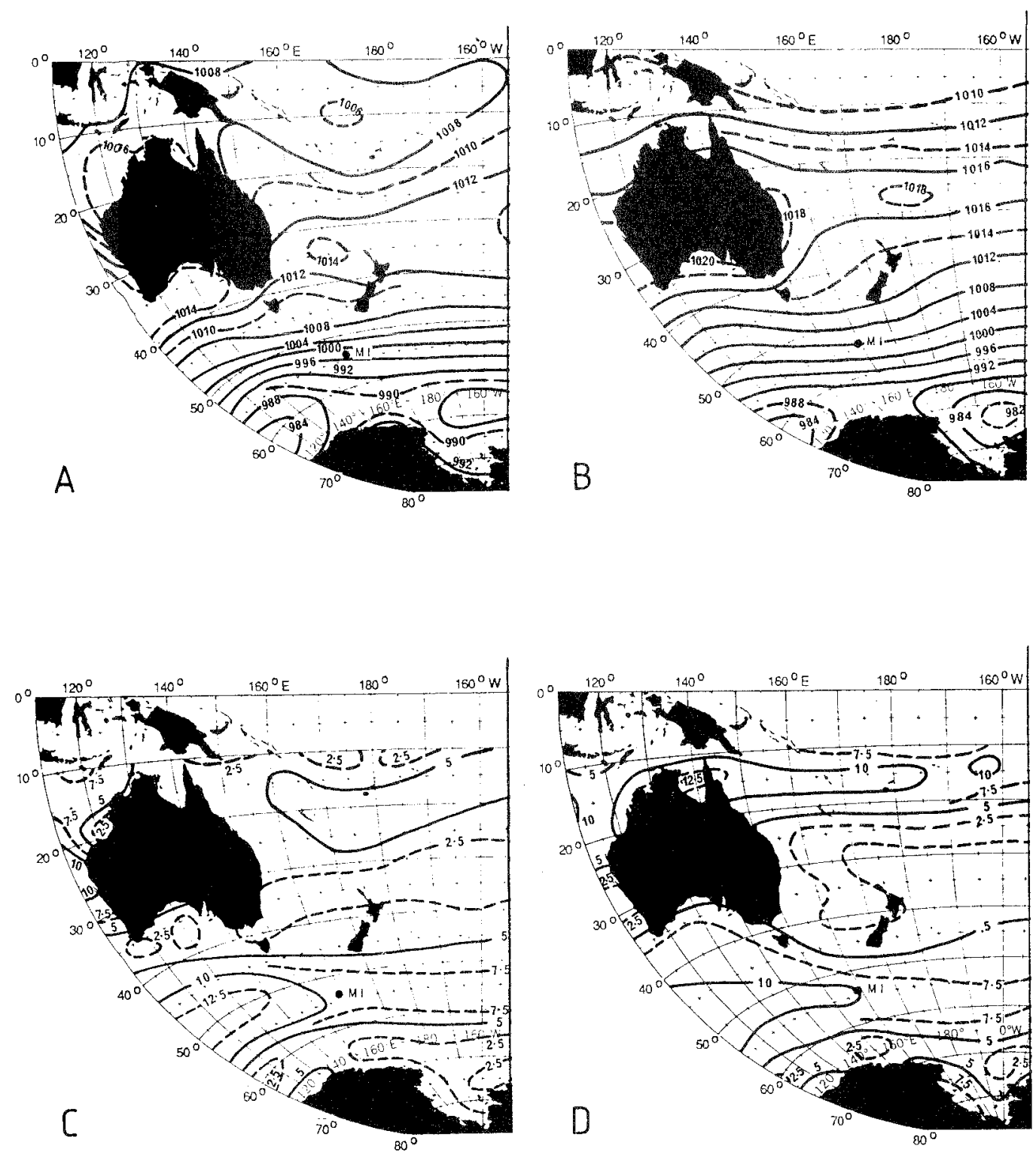

FIG. 2 -- Mean sea-level pressure ( $\mathrm{PPa}$ ) in (A) January and (B) July based on data from Taljaard et al. (1969). Mean surface geostrophic windspeed $\left(\mathrm{ms}^{-1}\right)$ in (C) January and (D) July based on data from Jenne et al. (I971). MI indicates location of Macquarie Island. 

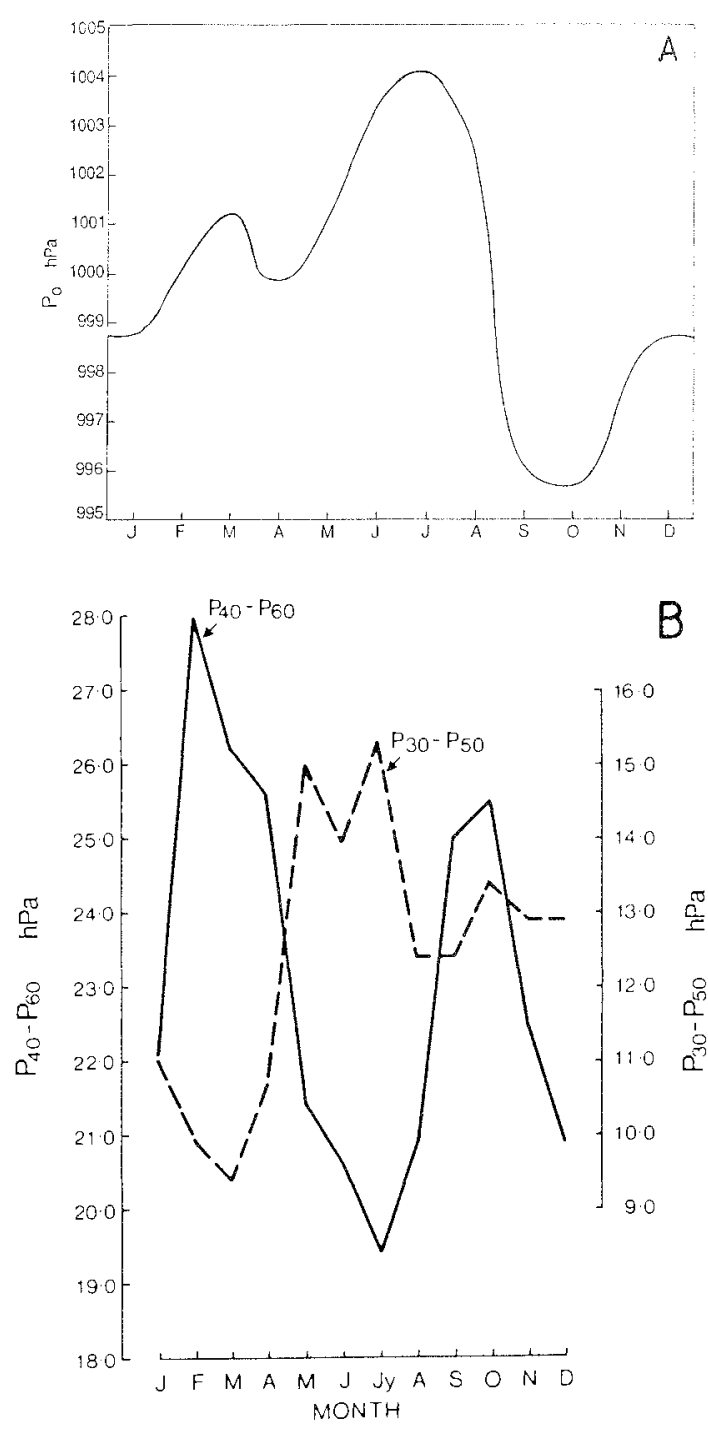

FIG. 3 - (A) Annual cycle of mean sea-level pressure $\left(P_{\mathrm{o}}\right)$ at Macquarie Island $(\mathrm{hPa})=$ $1 / 2(0900 h+1500 h)$; available data 1948-83. (B) Annual cycle of pressure gradients between $40^{\circ} \mathrm{S}$ and $60^{\circ} S$ and between $30^{\circ} S$ and $50^{\circ} S$; (1972-77) averaged over Pacific longitudes; after Streten \& Zillman (1984).

Western Australia. The mean wind flow over the island is thus northwest to westerly. The circulation of the Southern Hemisphere is characterised by a semi-annual change of pressure gradient (and consequently of windspeed) between middle and
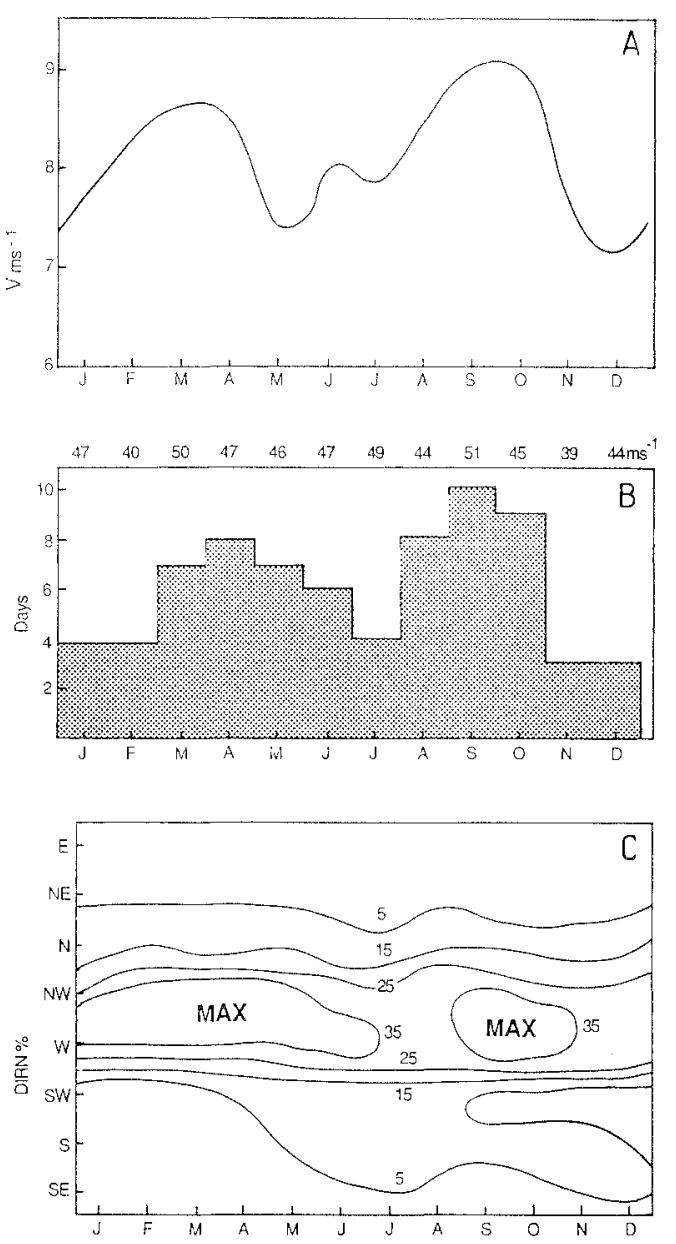

FIG. 4 - Wind data for Macquarie Island. (A) Mean windspeed $V$; all years 1948-83. (B) Mean number of days of gale (i.e. days with winds $>17.5$ $\mathrm{ms}^{-1}$ ) for the period 1967-83; figures above the histogram indicate highest gust $\left(\mathrm{ms}^{-1}\right)$ as measured by a Dines Anemograph for all years 1949-83. (C) Frequency of wind direction (\%) at $0900 \mathrm{~h}$ for all speeds (all years 1948-83).

high latitudes. This has been analysed by van Loon (1967) and attributed by him to different seasonal temperature trends in middle and high latitudes, and ultimately to different responses of the ocean heat balance at different latitudes and seasons. The annual cycle of mean sea-level pressure at Macquarie Island is shown in figure $3 \mathrm{~A}$ and the semiannual variation of pressure gradient averaged over a span of South Pacific longitudes in figure 3B. 
The latter indicates, between $40^{\circ} \mathrm{S}$ and $60^{\circ} \mathrm{S}$, larger pressure gradients and thus stronger winds in spring and autumn than in summer and winter. This genera lobservation for the hemisphere is also apparent in data on mean surface windspeed (fig. 4A) and the frequency of gales for Macquarie Island (fig. $4 \mathrm{~B}$ ), as is the predominant west to northwest directional frequency throughout the year (fig. $4 \mathrm{C}$ ). The extension of this flow throughout the troposphere is shown in the mean vector wind data at standard pressure levels for mid-season months at Macquarie Island in table 1.

The hemispheric westerly annulus is the domain of the great mid-latitude cyclones or depressions which form throughout the year as vortices within the westerly flow and whose associated frontal systems bring periods of severe weather to the southern parts of the Southern Hemisphere continents. In the Australasian region such weather systems most frequently form in the central to eastern South Indian Ocean sector and move generally to the east and southeast, controlled by the prevailing west to northwest flow in the upper air. The cyclones are readily identified in satellite imagery by their characteristic cloud vortices, an example of which is shown in plate 1 , and data can be obtained on their evolution and track (Streten \& Troup 1973, Carleton 1979). Analyses of mean track data derived from satellite and conventional observations (e.g. fig. 5) show the centres frequently passing close to the island. The gales, rain, snow and heavy seas associated with the passage of the depressions and associated frontal systems are characteristic of the Macquarie Island climate; on average, a front or depression centre probably passes the island once every five or six days. Such events are significant in the human history of Macquarie Island, which includes many shipwrecks, and tragedies due to severe weather.

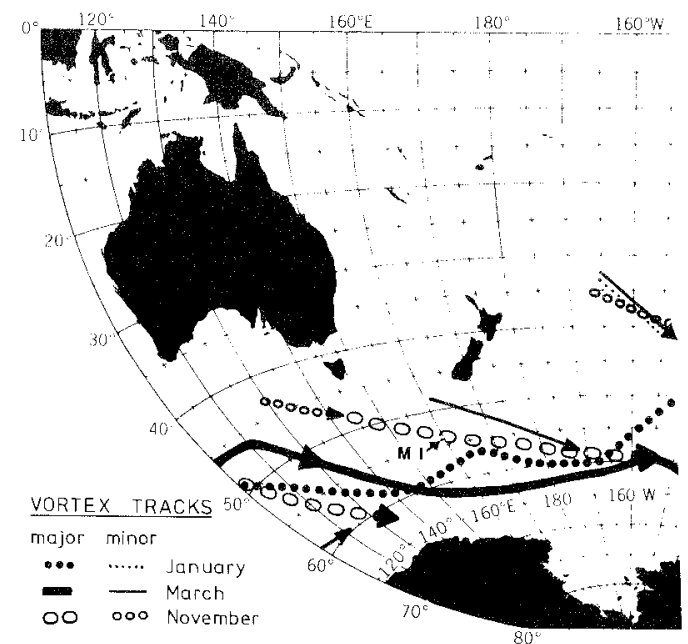

FIG. 5 - Vortex (depression) track diagram. Data from Streten \& Troup (1973). MI indicates the position of Macquarie Island.

TABLE 1

Mean vector winds (degrees $/ \mathrm{ms}^{-1}$ ) - upper air, Macquarie Island

Available data 1953-83; number of observations approx. 750 for each month and level.

\begin{tabular}{lrrrrr}
$\begin{array}{l}\text { Pressure } \\
\text { level (hPa) }\end{array}$ & $\begin{array}{c}\text { Approx. } \\
\text { ht }(\mathbf{m})\end{array}$ & January & April & July & October \\
\hline 900 & 850 & $283 / 11$ & $282 / 14$ & $283 / 10$ & $280 / 14$ \\
850 & 1310 & $281 / 12$ & $281 / 15$ & $282 / 10$ & $279 / 15$ \\
700 & 2830 & $279 / 14$ & $280 / 17$ & $278 / 12$ & $277 / 17$ \\
500 & 5350 & $278 / 19$ & $278 / 22$ & $278 / 15$ & $277 / 23$ \\
300 & 8860 & $280 / 24$ & $279 / 27$ & $276 / 17$ & $276 / 28$ \\
200 & 11470 & $278 / 20$ & $279 / 25$ & $276 / 21$ & $277 / 28$ \\
100 & 15930 & $284 / 10$ & $282 / 18$ & $275 / 29$ & $277 / 26$ \\
\hline
\end{tabular}


PLATE I

Satellite imagery of the Southern Ocean from a U.S. Defence satellite, showing depression vortex and frontal structure extending northwestward from the Macquarie Island region, with convective cloud activity to the west of the vortex centre.

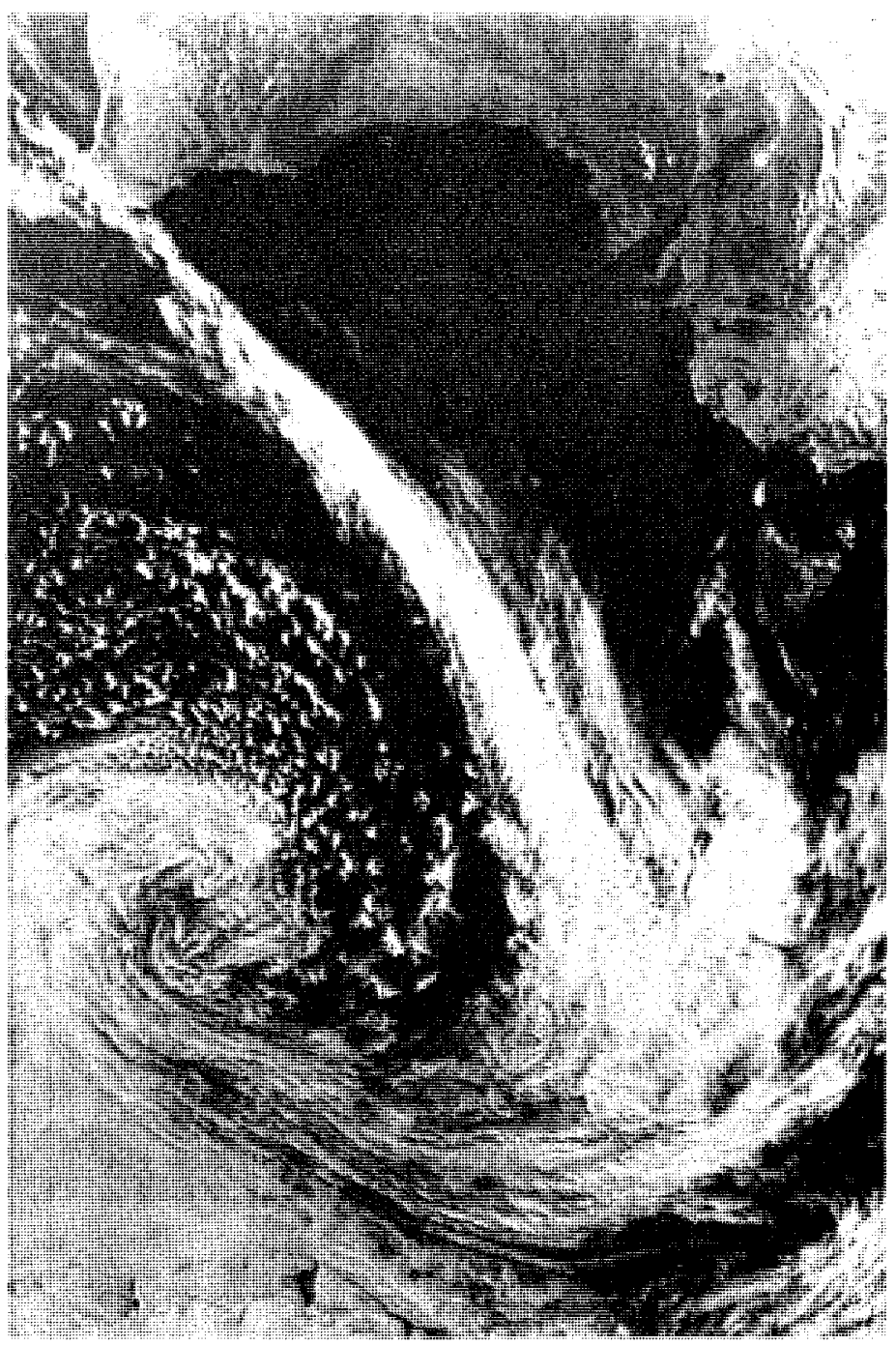

For example, the Australian sealer Hasselborough, the first known visitor to the island in 1810 reported the finding of the wreckage of an old fashioned ship on the shore, and the Commonwealth Fisheries ship Endeavour foundered with all hands after relieving the staff of the meteorological station in December 1914.

The $34 \mathrm{~km}$ elongated NNE-SSW ridge of the island (fig. 1B), rising generally to over $200 \mathrm{~m}$ and in parts to over $300 \mathrm{~m}$ above sea level, intercepts the wind flow from all directions. This results in local lee vortices, particularly in the region of Buckles
Bay, where the topographic effects of the detached $100 \mathrm{~m}$ peak of Wireless Hill, the low-lying isthmus and the northern end of the main island ridge, result in variations in lee wind patterns in the prevailing general westerly flow, which of ten cause difficult conditions during ANARE ship-to-shore operations.

The longitude of Macquarie Island, which determines the small but significant northerly component observed in the general westerly flow, is also important in a further aspect of the broadscale atmospheric circulation, viz. the high frequency of 


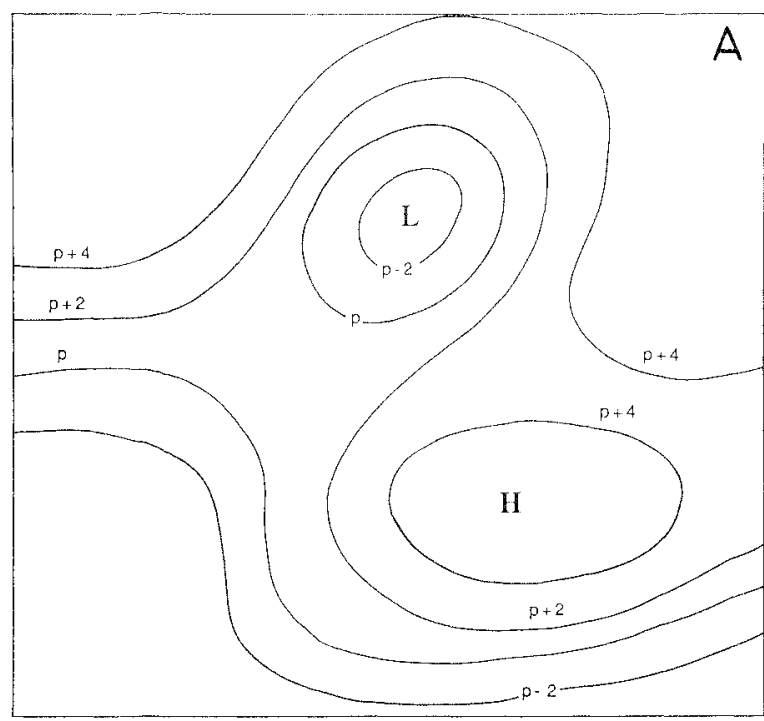

FIG. 6 - (A) Schematic pressure field associated with a blocking pattern (see text). (B) Annual pattern of the variability (degrees of latitude) of the mean monthly $1015 \mathrm{hPa}$ isobar poleward of the subtropical axis of high pressure for the southern hemisphere; data for 1972-77 after Streten (1980).

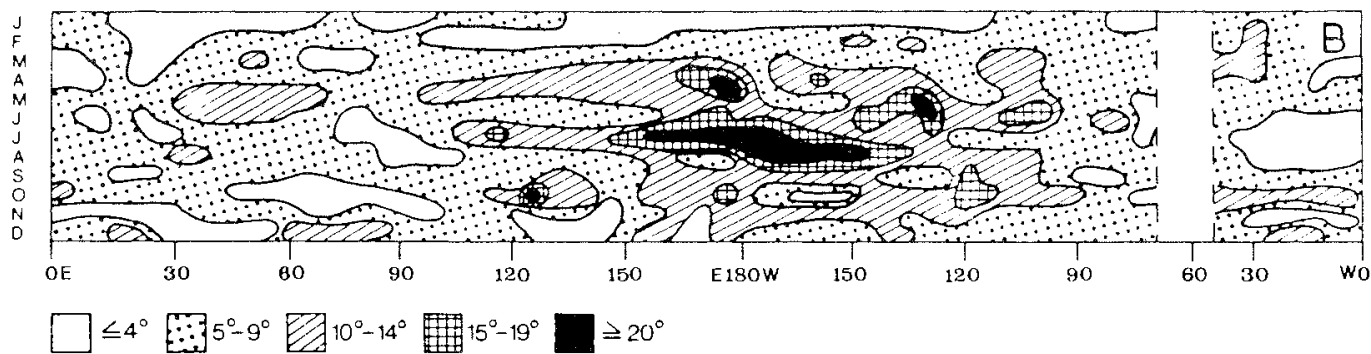

so-called "blocking" phenomena which profoundly affect the weather of the southern Tasman Sea in general and that of Macquarie Island in particular. A classical blocking pattern is associated with a splitting of the upper westerly flow and the extension of high pressure into the higher latitude westerlies with lower pressure at low latitudes as shown in figure 6A. Observational studies such as those of Wright (1974) indicate that the southern Tasman Sea and adjacent regions experience a high frequency of blocking, particularly in winter. This is also revealed in data on the latitudinal range of an isobar of mean monthly pressure; e.g. figure $6 \mathrm{~B}$ indicates the uniquely high variability of the circumpolar $1015 \mathrm{hPa}$ isobar poleward of the axis of high pressure at the longitudes of the Tasman Sea and extending eastward of New Zealand. Blocking patterns in this region are important to the weather at Macquarie Island in disrupting the progression of depressions eastward in the westerlies and producing persisting high pressure to the east. This frequently results in prolonged periods of northerly flow which, by transferring moist warmer air from lower latitudes over the colder Southern Ocean, cause vast areas of fog over the waters surrounding the island. Fogs are also common in northerly air flow ahead of frontal changes, and are observed at Macquarie Island on average about 70 days each year, distributed fairly evenly in all months. 

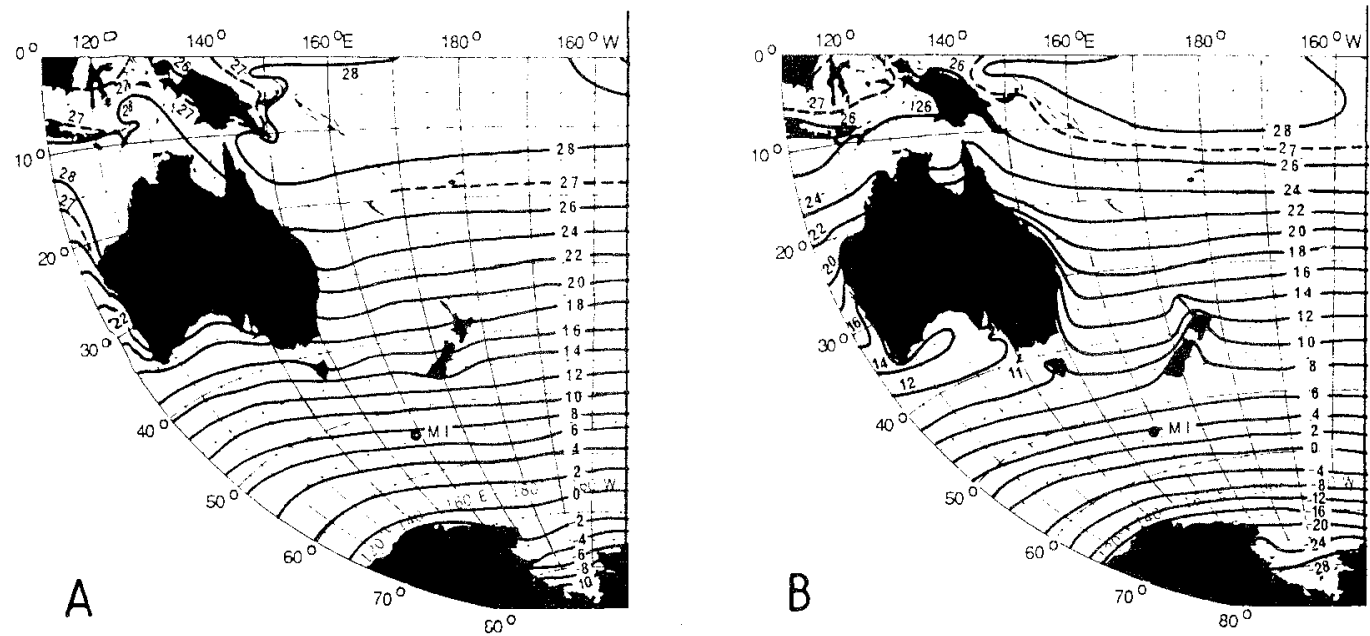

FIG. 7 --Surface mean air temperature ${ }^{C} C$ ) for (A) January and (B) July. Data from Taljaard et al. (1969). $M I$ indicates the position of Macquarie Island.

\section{TEMPERATURE AND HUMIDITY}

The patterns of surface mean air temperature over the region in January and July are shown in figure 7 , the most notable features being the difference between conditions over the ice-free waters in January and the pack ice zone in the same area in July, when the ice edge lies only some 300 to $400 \mathrm{~km}$ south of the island (fig. 8).

The chief characteristics of Macquarie Island temperatures shown in figure 9 are the relatively small annual variation and the absence of very marked extremes. An analysis of mean seasonal temperatures typical of oceanic islands at these southern latitudes (Streten 1977b) indicates, as would be expected from their locations, that temperature conditions at Campbell Island, Kerguelen Island, Marion Island and the Falkland Islands (Stanley) are very similar to those at Macquarie Island, with mean summer temperatures at all locations lying between $5^{\circ} \mathrm{C}$ and $10^{\circ} \mathrm{C}$ and mean winter temperatures between $0^{\circ} \mathrm{C}$ and $-5^{\circ} \mathrm{C}$. However, island stations lying south of the Antarctic Convergence (though not necessarily south of Macquarie), e.g. Heard Island, experience much more severe temperatures. Figure 10 compares the interannual variability of mean seasonal temperature for higher Southern Hemisphere locations, and indicates that in winter this increases from middle to high latitudes over the oceans, reaching a maximum within the pack ice fringe. In summer, however, in the absence of the pack ice, all the islands experience a similar interannual variability.
The mean relative humidity experienced throughout the year at $0900 \mathrm{~h}$ local time is also shown in figure 9. The data are almost identical with those observed at $1500 \mathrm{~h}$ local time and are typical of those at oceanic islands in mid-latitudes. Because of the low temperatures, however, the absolute humidity (i.e. the actual amount of water vapour per unit volume of air) is always relatively low. Mean upper air temperatures at standard pressure levels for mid-season months are shown in table 2 , with mean water vapour content expressed in terms of mixing ratio (grams of water vapour per kilogram of air)

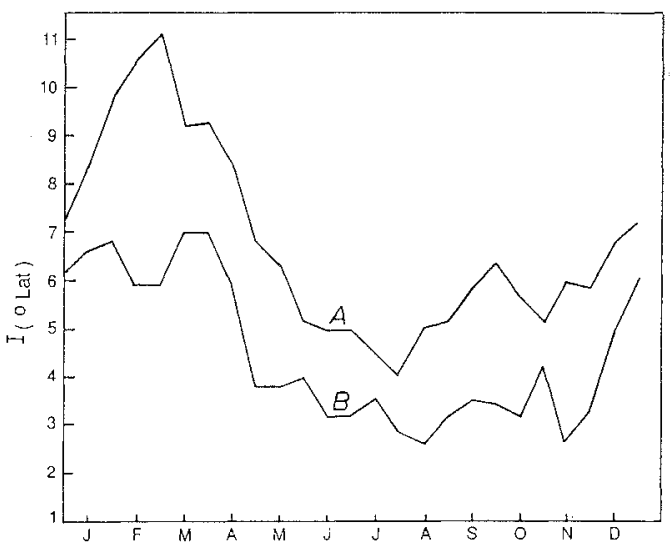

FIG. 8 - Separation of Macquarie Island from the pack ice edge I (degrees of latitude) at $159^{\circ} \mathrm{E} .(\mathrm{A})$ mean, (B) minimum. Data for period 1973-82 from Naval Oceanography Command (1985). 
FIG. 9 - (A) Temperalure data for Macquarie Island - A, extreme daily maximum; B, mean daily maximum; $\mathrm{C}$, mean daily minimum; $\mathrm{D}$, extreme daily minimum; $\mathrm{E}$, mean terrestrial minimum (all available data, 1948-83). (B) Mean relative humidity (\%) at $0900 \mathrm{~h}$ (all available data 1948-83).

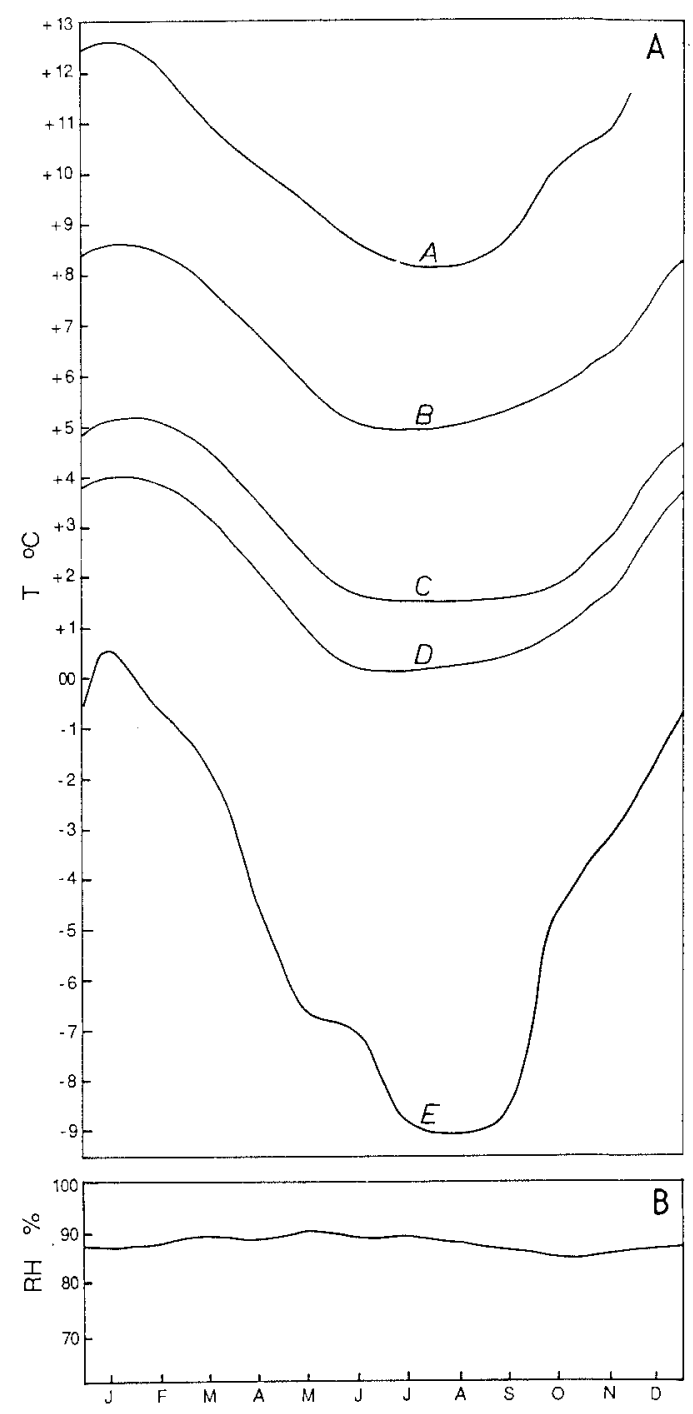

TABLE 2

Mean upper air temperatures $\left({ }^{\circ} \mathrm{C}\right)$ and mixing ratios $(\mathrm{gr} / \mathrm{kg})$, Macquarie Island

Available data 1950-82, total number of observations approx. 750 for each month and level.

\begin{tabular}{|c|c|c|c|c|c|}
\hline $\begin{array}{l}\text { Pressure } \\
\text { level }(\mathbf{h P a})\end{array}$ & $\begin{array}{c}\text { Approx. } \\
\text { ht (m) }\end{array}$ & January & April & July & October \\
\hline 900 & 850 & $1.3(3.5)$ & $0.2(3.2)$ & $-2.1(2.8)$ & $-2.0(2.7)$ \\
\hline 850 & 1310 & $-0.5(3.0)$ & $-1.9(2.6)$ & $-4.1(2.2)$ & $-4.3(2.1)$ \\
\hline 700 & 2830 & $-7.2(1.4)$ & $-9.1(1.2)$ & $-11.7(0.8)$ & $-11.6(0.9)$ \\
\hline 500 & 5350 & $-22.2(0.5)$ & $-24.7(0.4)$ & $-28.9(0.2)$ & $-27.3(0.3)$ \\
\hline 300 & 8860 & $-46.1\left(^{*}\right)$ & $-49.1\left(^{*}\right)$ & $-55.0\left(^{*}\right)$ & $-50.5(*)$ \\
\hline 200 & 11470 & $-49.3\left(^{*}\right)$ & $-54.3\left(^{*}\right)$ & $-60.9\left(^{*}\right)$ & $-52.5\left(^{*}\right)$ \\
\hline 100 & 15930 & $-49.1(*)$ & $-53.5\left(^{*}\right)$ & $-58.2\left(^{*}\right)$ & $-48.9\left(^{*}\right)$ \\
\hline
\end{tabular}



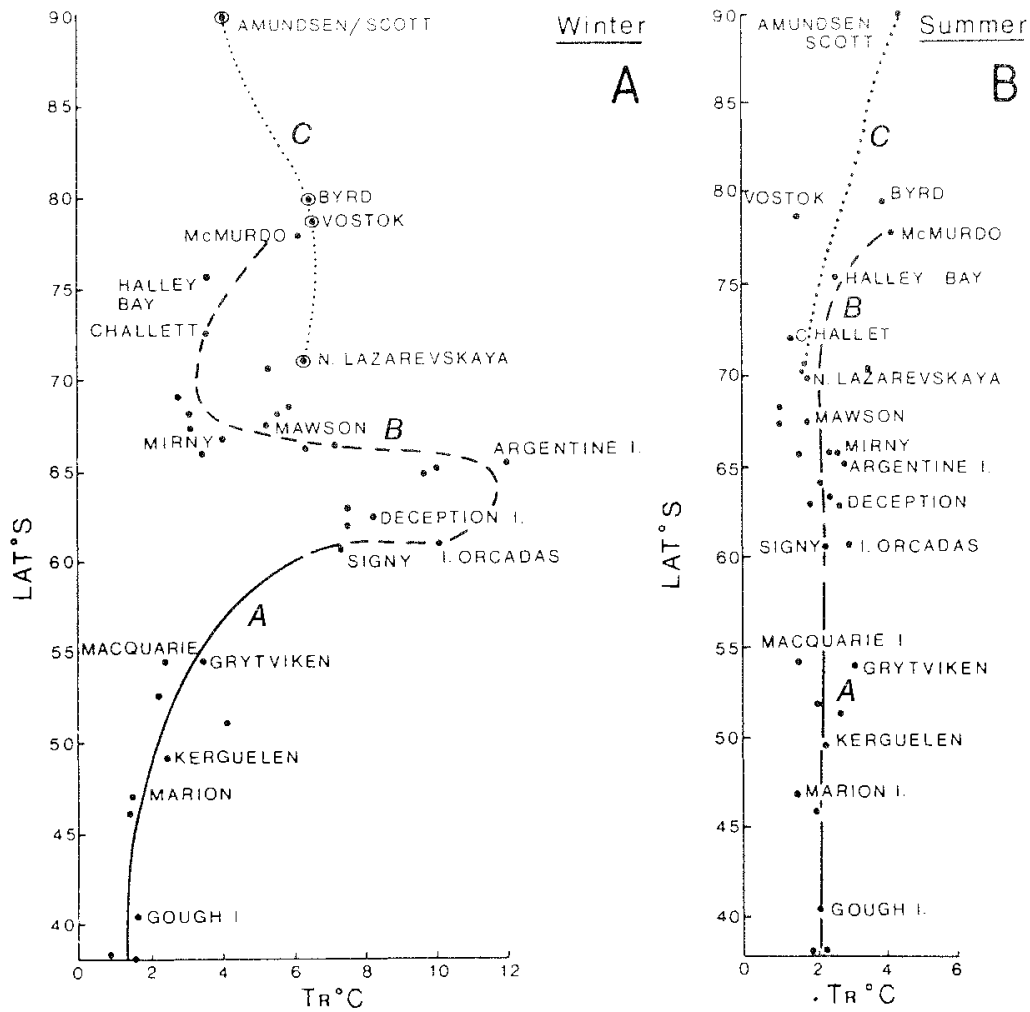

FIG. 10 - Latitudinal variation in the range of the mean seasonal temperature $\left(T_{\mathrm{R}}\right)$ for high latitude stations in (A) winter (June to September) and (B) summer (December to March). A - the southern oceans; B - the pack ice zone and coastal Antarctica: C - continental Antarctica (after Streten 1977a).

\section{SUNSHINE, CLOUD AND PRECIPITATION}

The generally low mean temperatures throughout the year are accompanied by a cloud cover averaging seven-eighths in all months, with the low mean hours of sunshine shown in table 3 . Cloud is generally low stratiform, typical of middle to high southern oceanic latitudes, frontal discontinuities being marked by passage of a zone of cloud of greater depth and substantial convective activity, but rarely with thunder. To the rear of a typical cold front (see plate 1) scattered convective cloud occurs as colder, higher-latitude air is destabilised over the relatively warmer water; however, the more typical stratiform pattern is soon re-established.

The island ridge lying across the flow of the westerlies ensures a high frequency of days on which precipitation occurs. This varies little in the

TABLE 3

Mean daily hours of sunshine - Macquarie Island

Available data 1948-53 and 1965-83.

\begin{tabular}{lcccccccccccc}
\hline Month & $\mathrm{J}$ & $\mathrm{F}$ & $\mathrm{M}$ & $\mathrm{A}$ & $\mathrm{M}$ & $\mathrm{J}$ & $\mathrm{J}$ & $\mathrm{A}$ & $\mathrm{S}$ & $\mathrm{O}$ & $\mathrm{N}$ & $\mathrm{D}$ \\
hours & 3.4 & 3.5 & 2.6 & 1.7 & 1.1 & 0.6 & 0.8 & 1.4 & 2.0 & 2.7 & 3.3 & 3.2 \\
\hline
\end{tabular}




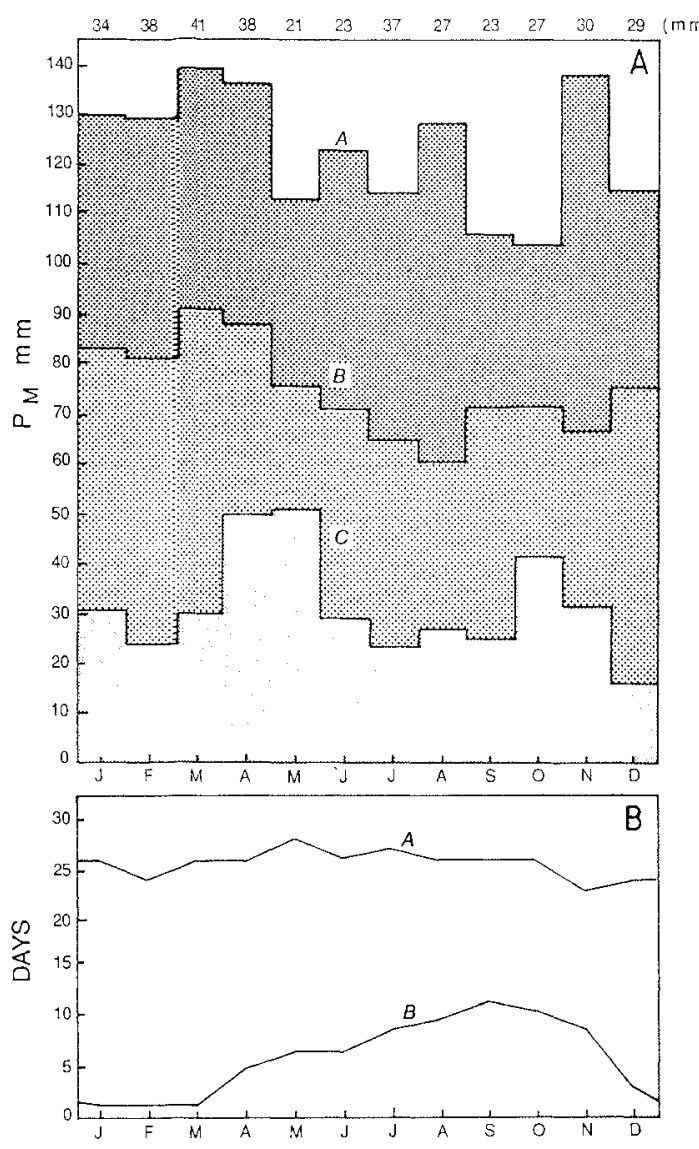

FIG. 11 - Precipitation data for Macquarie Island. (A) Monthly total $\left(P_{\mathrm{M}}\right)$. A - maximum; $\mathrm{B}$ - mean; $\mathrm{C}$ - minimum; figures above the diagram show the highest observed 24-hour precipitation $(\mathrm{mm})$ (all available data 1948-83). (B) Mean number of days per month with $A$-precipitation $>0.1 \mathrm{~mm}$ (all available data 1948-83); B - observed snowfall (data 1967-83).

mean from month to month throughout the year (fig. 11B) and totals some 308 days annually. Snowfall occurs throughout the year, with a maximum frequency in spring. Monthly precipitation amounts shown in figure 11(a) also vary little from month to month, with an annual average over 32 years of $901 \mathrm{~mm}$. This amount is compared, in figure 12, with that observed at other Southern Ocean islands, and indicates the general decrease in annual precipitation with increasing latitude (and lower temperature and absolute humidity).
The upper levels of the plateau of Macquarie Island are covered with wet snow for much of the year, particularly from May to October, and depths in level areas may reach 0.5 to $1.0 \mathrm{~m}$ at the end of the season (P. Ruckert, pers. comm.).

\section{MACQUARIE ISLAND AS AN OBSERVATION STATION}

Although the earlier observations from the 1911-14 period were recognised as valuable for weather forecasting for southern Australia and New Zealand, it was only with the introduction of Northern Hemisphere concepts of frontal analysis to the Australasian region in the 1930's and 1940's (initially by $\mathrm{E}$. Kidson in New Zealand - see Kidson \& Holmboe 1935) that the full utilisation of observations from isolated stations such as Macquarie Island became possible. Initially, such studies were carried out retrospectively (Kidson 1947), but with the establishment of a number of stations reporting regularly several times a day by radio (including the ANARE bases at Macquarie Island and Heard Island) in the late 1940's, attempts began at coherent operational meteorological analysis for large sectors of the Southern Ocean. In Australia, such work was pursued in the Bureau of Meteorology offices in Melbourne and Hobart (e.g. Gibbs et al. 1952, Langford 1957, 1960); this complemented the very extensive studies being carried out by J.J. Taljaard and H. van Loon at the South African Weather Bureau and those at the Massachusetts Institute of Technology in the early

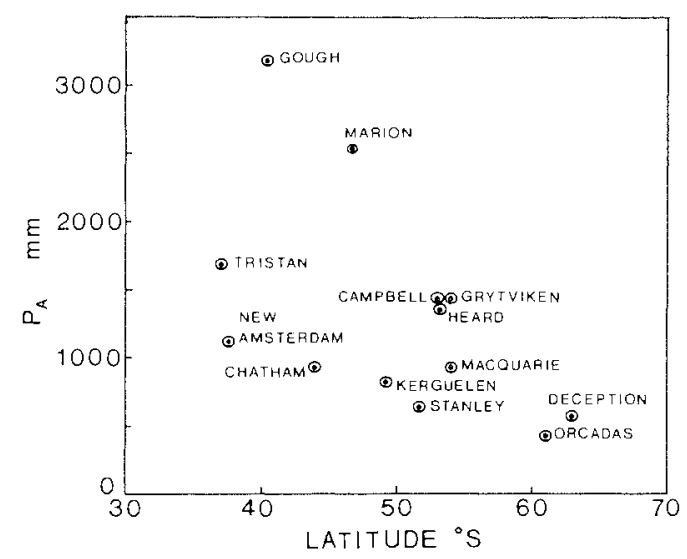

FIG. 12 - Long-term mean annual precipitation $P_{\mathrm{A}}(\mathrm{mm})$ as a function of latitude for Southern Hemisphere islands (data from Streten 1977b). 
FIG. 13 - International drifting buoy network in December 1986 in the Australian region. A-Australia, $N-$ New Zealand, $S$ - South Africa, $U$ - United States, $P$-other.

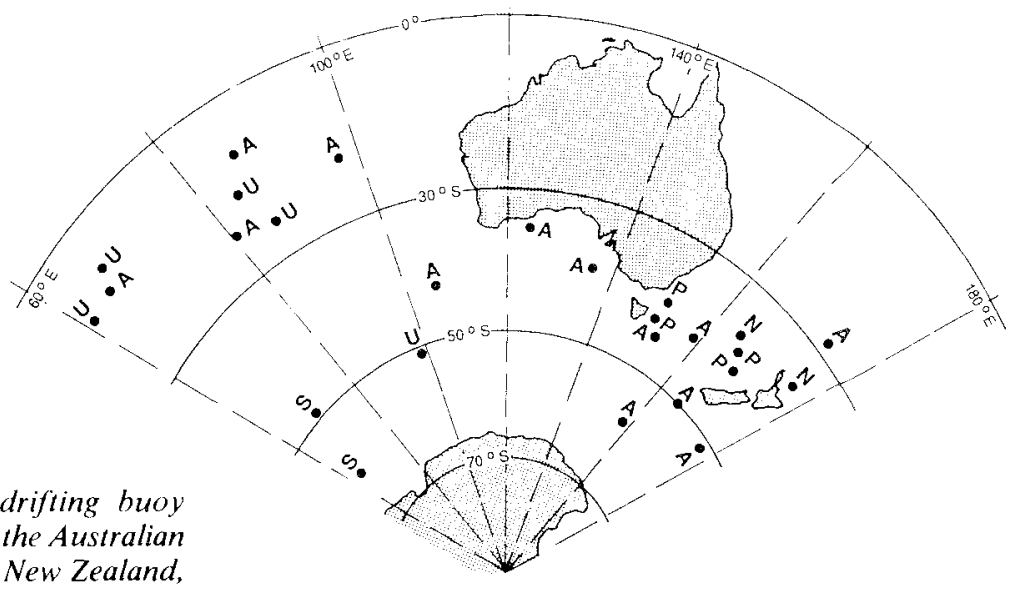

an international fleet of satellite-reporting drifting buoys was deployed on the Southern Ocean. These provided a limited surface pressure network and "ground truth" observations necessary for the derivation of the upper air temperature profiles from the satellite data. The demonstration of the value of the buoys during FGGE has led to a gradual re-establishment of the internationally funded drifting buoy network, and figure 13 shows an example of the operational data currently available on a day-to-day basis.

With such developments the unique value to synoptic analysis of the individual ocean stations, such as Macquarie Island, has diminished but not disappeared. Representative and accurate observations from various ocean sites are still required to calibrate the global satellite data, and Macquarie Island has recently been selected by the World Meterological Organization (WMO) as one such baseline station. Its regular observations programme (see table 4 ) provides a long-term record of climate at a fixed site.

As indicated in figure 1 almost all suitable islands of the Southern Ocean have now been utilised as observing points in the WMO concept of the World Weather Watch (WWW). Australia plays its part in this programme over the Southern Ocean by maintaining the surface and upper air observation station at Macquarie Island and an unmanned Automatic Weather Station (AWS) on Heard Island, in providing buoys to the international fleet and in making the derived data 
available on the Global Telecommunications System (GTS) for global analysis and research. It is only such international co-operation in providing free exchange of data that makes operational meteorology possible. Wealthier countries, such as the USA, USSR, Japan and the European Community, provide complex and costly satellite systems for global observation of some parameters, while smaller nations contribute conventional station data from their territories. Thus, no part of the WWW system can entirely dispense with another in present-day operational meteorology, where a continuing three-dimensional global data coverage is essential to provide data for the complex numerical models now used in weather forecasting.

\section{TABLE 4}

\section{Observation programme on Macquarie Island in 1986}

Type of observation

Daily observation times (GMT)

Continuous record

\section{SURFACE:}

Temperature

Pressure

Wind direction

Wind speed

Visibility, cloud cover

Humidity

Precipitation

Sunshine hours

Wind run

UPPER AIR:

Winds

Pressure, temperature and humidity

OZONE:

Total content

Vertical distribution

RADIATION:

Global

Diffuse

TRACE GAS ANALYSIS:

Carbon dioxide

\section{MACQUARIE ISLAND AS \\ A MONITORING STATION FOR BROADSCALE CLIMATIC INDICATORS, ATMOSPHERIC CONSTITUENTS AND CLIMATE CHANGE}

Over recent years, both scientific literature and the popular press have shown an increasing interest in possible gross changes to the earth's climate system and in potential strategies to alleviate natural changes and prevent those which might be caused by the actions of man. In all such investigations, an accurate and sufficiently long data record from geographical locations wellspaced across the globe is essential. Long-term observations from such stations as Macquarie Island, which, unlike many on the continents, are unaffected by increasing urbanisation, local industrial activity, vegetation change or major alterations

$\begin{array}{ll}0200,0500,0800,1100 & \text { yes } \\ 1400,1700,2000,2300 & \text { yes } \\ & \text { yes } \\ & \text { yes } \\ & \text { no } \\ & \text { yes } \\ \text { Daily total } & \text { yes } \\ 2300 & \text { yes } \\ 0500,1100,1700,2300 & \text { no } \\ 1100,2300 & \text { no } \\ \text { Measured } 3 \text { times a day } & \text { no } \\ \text { during winter, } 5 \text { times a day other seasons } & \text { no } \\ \text { At least twice a month } & \text { no } \\ \text { Half-hourly intervals } & \\ & \text { yes } \\ \text { 2-4 samples per month; } & \text { yes } \\ \text { sampling duration } 8 \text { hours and } 24 \text { hours } & \text { no }\end{array}$




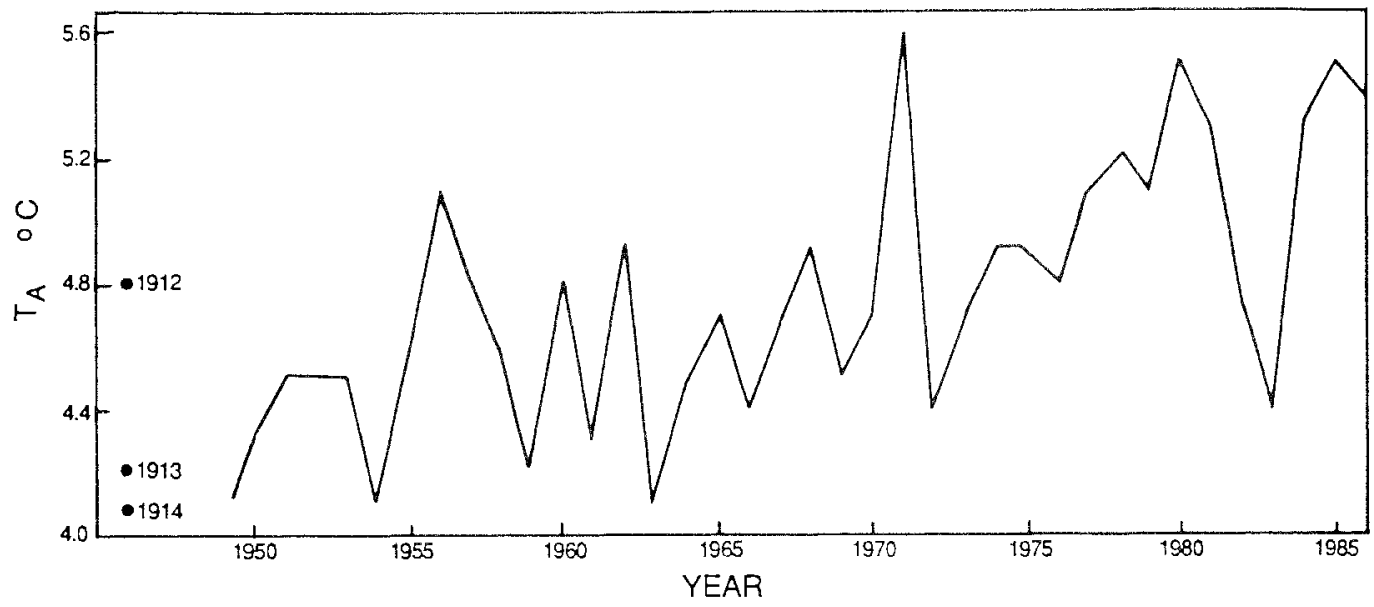

FIG. $14-$ Mean annual temperature $T_{\mathrm{A}}=1 / 2$ (mean annual max. + mean annual min.) for Macquarie Island. Points for 1912,1913,1914 are calculated from data given by Kidson (1946).

to the local site characteristics, are particularly valuable in monitoring the possible long-term trends in the climate record. This is particularly so in higher latitude regions, where some of the possible changes may be earlier and more readily detect able, e.g. global atmospheric warming resulting from increased $\mathrm{CO}_{2}$ and other greenhouse gases. Our ability to assess the reality of some of the proposed mechanisms, trends and climate modelling results depends on a very careful analysis of all the characteristics of the record at many locations. Such analyses are not always performed with a cognisance of the natural variability and the complexities involved, e.g. some views that have been advanced over the past 15 years are:

(1) A belief that a global cooling had commenced, consistent with apparent sudden climatic changes observed in some proxy records of past climate and with the statistical evaluation that the present interglacial period should be drawing to an end. The observational evidence advanced was some years of satellite-derived data, which showed an apparently increasing seasonal snow cover over the Northern Hemisphere continents. The trend, however, soon reversed; more accurate data now available show the areal snow cover exhibiting yearly fluctuations around a mean with no continuous increase.

(2) A belief that global warming had commenced, based on the satellite observation of a decline in antarctic sea ice extent for the first five years that such data were available. Again, the trend reversed; present observations show fluctuations in particular sectors at different times but no persisting decrease.
(3) A belief that global warming has been progressing for at least a century, following from the increased industrial emission of $\mathrm{CO}_{2}$ and other greenhouse gases. Numerous manipulations of existing long-term temperature data have been made with various results; many are inconclusive, but the most recent (Jones et al. 1986) indicates a probable mean Southern Hemisphere rise of $0.5^{\circ} \mathrm{C}$ over the past century. This assessment does not show the cooling trend between 1938 and 1965 which is apparent in the overall warming of the Northern Hemisphere over the past century. However, the representativeness and accuracy of much of the data, particularly over the Southern Hemisphere oceans is still questionable. The Macquarie Island data (fig. 14) show an apparent slight upward trend in mean temperature since 1949 but the significance of such data must be considered in the light of many other observations at other locations.

The fact of the atmospheric $\mathrm{CO}_{2}$ steadily increasing during the period of accurate observation since the 1950 's, and probably (though less well documented) since the last century, is the one item of data which supports the possibility of an anthropogenetically induced climate warming. However, the basic quantitative global data and time coefficients of the carbon cycle in the atmosphere and oceans (particularly the Southern Ocean) are not accurately known. Experiments with numerical models, however, indicate various results, depending on the characteristics of the model and the inclusion or exclusion of particular physical processes, such as the ocean effects and cloud characteristics. The most reliable appear to 
project an increased global temperature of $3^{\circ} \mathrm{C} \pm$ $1.5^{\circ} \mathrm{C}$ with a doubling of $\mathrm{CO}_{2}$ which, if present rates continue, might occur within 50 to 100 years.

Simila rly, the recent discovery of the recurring springtime $\mathrm{O}_{3}$ "hole" over Antarctica over a number of years has raised questions of its origin and the chemical and dynamical processes at work: these are as yet unresolved but possible ramifications cont inue to excite widespread, but not always considered comment.

In all such data studies, modelling and public debate, a cautionary note must be sounded. Shortterm trend observations of some quantities proved to be delusive in providing evidence of some theories of global climate change that otherwise appeared to have a not-unreasonable theoretical basis. Similarly, the duration of observational record in relation to the complex chemical and physical processes which may be occurring in the atmosphere and ocean, with $\mathrm{CO}_{2}, \mathrm{O}_{3}$, and the other greenhouse gases, needs to be considered; it may not always be obvious what time spans in observed fluctuations are important. Thus, measurement of $\mathrm{O}_{3}$ has been progressing for over 30 years at Macquarie Island; these data are now being reevaluated in the light of the recent observations in the antarctic which raise the possibility of an extension of the "hole" to lower latitudes. The importance of long-term records has been stressed at some length, because such an "observatory" activity is often unpalatable to many short-term scientific investigators and always to those meeting the cost of a programme continuing over many decades.

\section{CONCLUSION}

An outline of the principal climatic elements of Macquarie Island has been given. The value of the observational data is apparent for the study of the great wealth of biological activity on the island, for the day-to-day analysis of hemispheric weather and for the long-term monitoring of possible climate change in a sensitive area of the at mosphereocean system.

\section{ACKNOWLEDGEMENTS}

The author is grateful to Mr D. Lee and Ms M. Jones of the Bureau of Meteorology National Climate Centre who provided basic statistical data and to Mr D. King and Mrs E. Russell of the Bureau of Meteorology who drafted many of the diagrams.

\section{REFERENCES}

ANARE, 1948-68: Australian National Antarctic Research Expeditions Reports, Ser. D, Meteorology (I-XX1). Antarctic Division, Melbourne

CARLETON, A.M., 1979: A synoptic climatology of satellite observed extratropical cyclone activity for the southern hemisphere winter. Arch. Met. Geophys. Bioklim., B27: 265-279.

GIBBS, W.J., GOTLEY, A.V. \& MARTIN, A.R., 1952 : Meteorology of Heard and Macquarie Islands 1948; part IC -...- Discussion. ANARE Rep., Ser. $D($ I). Antarctic Division, Department of External Affairs, Melbourne.

JENNE, R.L., CRUTCHER, H.L., VAN LOON, H. \& TALJAARD, J.J., 1971: CLIMATE OF THE UPPER AIR, SOUTHERN HEMISPHERE: IV. NAVAIR 50-IC-57. U.S. Navy, Washington, D.C.

JONES, P.D., RAPER, C.B. \& WIGLEY, T.M.L., 1986: Southern hemisphere surface air temperature variation 185i-1984. J. Clim. Appd Met., 25: $1213-1230$

KIDSON, E., 1946: Discussion of observations at Adelie Land, Queen Mary Land and Macquarie Island. Australasian Antarctic Expedition 1911-1914 (AAE). Sci. Rep., Ser. B(VI). Government Printing Office, Sydney.

KIDSON, E., 1947: Daily weather charts extending from Australia and New Zealand to the Antarctic continent. AAESci. Rep., Ser. B(VII). Government Printing Office, Sydney.

KIDSON, E. \& HOLMBOE, J., 1935: FRONTAL METHODS OF WEATHER ANALYSIS APPLIED TO AUSTRALIA-NEW ZEA$L A N D$ AREA: Part I - Discussion, Part II - Weather Charts. N.Z. Department of Science and Industrial Research Meteorological Bureau, Wellington.

LANGFORD, J.C., 1957: Southern Ocean analysis with special reference to the period December 1954 to March 1955. Aust. Met. Mag., 15: 1-22.

LANGFORD, J.C., 1960: Aspects of the circulation and analysis of the Southern Ocean. In $A N T A R C$ TIC METEOROLOGY. Pergamon, Oxford: $256-273$.

NAVAL OCEANOGRAPHY COMMAND, 1985: SEA ICE ATLAS: I, Antarctic. NAVAIR 50-IC-540 NSFL MS 39524-500. U.S. Navy, Washington, D.C.

NEWMAN, B.W., 1929: Tabulated and reduced records of the Macquarie Island station. AAE Sci. Rep., Ser. B(III). Government Printing Office, Sydney.

STRETEN, N.A., 1977a: Aspects of the year to year variation of seasonal and monthly mean station temperature over the southern hemisphere. Mon. Wea. Rev., 105: 195-206.

STRETEN, N.A., 1977b: Seasonal climatic variability over the southern oceans. Arch. Met. Geophys. Bioklim., B25: 1-19. 
STRETEN, N.A., 1980: Some synoptic indices of the southern hemisphere mean sea level circulation 1972-1977. Mon. Wea. Rev., 108: 18-36.

STRETEN, N.A. \& TROUP, A.J., 1973: A synoptic climatology of satellite observed cloud vortices over the southern hemisphere, Quar. J. R. Met. Soc. 99: 56-72.

STRETEN, N.A. \& ZILLMAN, J.W., 1984: Climate of the South Pacific Ocean. In H. van Loon (Ed.): CLIMATES OF THE OCEANS. Elsevier, Amsterdam: 263-429.

TALJAARD, J.J., VAN LOON, H., CRUTCHER, H.L. \& JENNE, R.L., 1969: CLIMATE OF THE UPPER AIR-SOUTHERN HEMISPHERE. NAVAIR 50-IC-55. U.S. Navy, Washington, D.C.
VAN LOON, H., 1967: The half yearly oscillations in middle and high southern latitudes and the coreless winter. J. Atmos. Sci., 24: 472-486

WRIGHT, A.D.F., 1974: Blocking action in the Australian region. Bur. Met. Melbourne, Tech Rep. 10.

ZILLMAN, J.W. \& MARTIN, D.W., 1968: A sharp cold frontal passage at Macquarie lsland in the southern ocean. J. Appl. Met., 7: 708 -711.

(accepted 30 June 1987) 